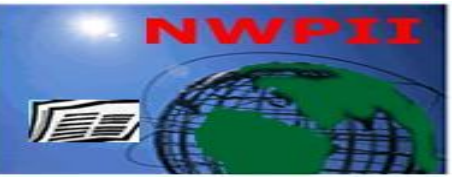

American Journal of Biomedical Sciences

ISSN: 1937-9080

nwpii.com/ajbms

\title{
Bacteriological Study of the Cervix of Females Suffering from Unexplained Infertility
}

\author{
Vijay Prabha*, Aanam, Teena Dhir and Siftjit Kaur
}

Department of Microbiology, Panjab University, Chandigarh-160014, India

* Corresponding author

Dr. (Mrs) Vijay Prabha

Department of Microbiology

Panjab University

Chandigarh -160014, India

E mail: satishvijay11@yahoo.com

Tel: 91-0172- 2534144

Fax: 91-0172-2541770

Received: 12 April 2010; $\mid$ Revised: 27 December 2010; $\mid$ Accepted: 23 February 2011

\begin{abstract}
The aim of the present study was microbiological investigation of cervical samples of females suffering from unexplained infertility. 16 women were evaluated by standard bacterial culture method. Among total cases, all showed at least one type of bacteria. In total 27 isolates were obtained and most of these bacteria were isolated several times from different specimens. Staphylococcus was the main microorganism isolated, other common microorganisms generally isolated were Escherichia coli, Pseudomonas, Streptococcus, Micrococcus and Bacillus. When the effect of 24 and $48 \mathrm{~h}$ old cell culture and cell free supernatant of cervical isolates on human motility was studied in vitro, the results showed that $63 \%$ isolates significantly decreased the sperm motility. Heat treated cell culture and cell free supernatant failed to inhibit sperm motility, suggesting the presence of heat labile proteins that may be responsible for decrease in spermatozoal motility. 5 out of 27 isolates were capable of agglutinating spermatozoa. Only washed cells/cell culture could agglutinate spermatozoa while cell free supernatant failed to do so. It seems that there may be certain ligands on bacterial cell surface responsible for sperm agglutination. These results in general suggest that, in vitro co-incubation of spermatozoa with cervical isolates does cause a significant decline in numbers of motile spermatozoa, however, what role do the microorganisms play in vivo has yet to be elucidated.
\end{abstract}

Keywords: cervix, bacteria, spermatozoa, immobilization, unexplained infertility.

\section{Introduction}

Bacterial infections have long been recognized as having an association with infertility
(Comhaire et al., 1999; Khalili and Sharifi-Yazdi, 2001). However, the significance of asymptomatic infections or bacterial colonization of the female or male genital tract is less well known (Naessons et al., 1986; Golshani et al., 2006). Many

(C) 2011 by NWPII. All rights reserved. 
investigators have raised the possibility that infections of the reproductive tract that are subclinical might be etiological factors in unexplained infertility (Fowler, 1981; Cottell et al., 2000). A major step in human reproduction is the transport of spermatozoa from the vagina to the site of fertilization. The uterine cervix with its unique anatomic and histologic structure and secretory function plays an important role in this process. Successful fertilization in most instances depends on a constant supply of sperm for some hours before and after ovulation at the site of fertilization. Spermatozoa are stored in the cervix and released continuously to the upper part of the reproductive tract. Abnormalities of the cervix and its secretions have become suspect as a causal factor in unexplained infertility. Therefore, a prospective study aimed at determining the bacterial isolation of cervix, its interaction with spermatozoa and its role was carried out.

\section{Materials and Methods}

\subsection{Microorganisms}

The bacterial isolates used in the present study were taken from the cervices of women suffering from unexplained infertility, attending the Department of Obstetrics and Gynaecology, Government Multi Speciality Hospital, Sector-16, Chandigarh, India. The cases of unexplained infertility were the women who were unable to conceive after two years of unprotected coitus and all other factors (anovulation, hyperprolactinemia, premature ovarian failure, tubal diseases, abnormalities of the cervix, endometriosis, luteal phase defects and other endocrine or medical disorders) responsible for infertility being ruled out.

\subsection{Isolation of microorganisms from the cervical area of human females}

Before taking the samples, the patients' recent medical history was taken into consideration. The cervical samples were taken from only those females who had not had any antibiotic intake for at least a week. The sample was taken only at that time when there was no clinical incidence of cervical infection. Therefore, all the cervical isolates which were obtained were considered to be normal flora. Swab samples were taken from the cervical area by the standard technique (Hok et al., 1967). The cervix was made visible with the help of speculum. The sample on sterilized cotton swabs moistened with physiological saline was taken from the cervical area in duplicates and care was taken not to contaminate the swab with the vaginal microflora. The samples were directly spread by streaking on sheep blood agar plates. The plates were incubated at $37^{\circ} \mathrm{C}$ for $48 \mathrm{~h}$ and observed for the bacterial growth. The isolates obtained from the plates were subjected to various tests of identification according to the characteristics laid down in the Bergey's Manual of Determinative Bacteriology (1994). The various isolates so obtained were maintained on nutrient agar slants.

\subsection{Sperms from human males}

Semen samples were obtained from males attending infertility clinic by masturbation into sterile vials. The ejaculates were collected from the clinical laboratory of Government Multi Speciality Hospital, Sector-16, Chandigarh, India. The samples were protected from the extremes of temperature i.e. not less than $20^{\circ} \mathrm{C}$ and not more than $40^{\circ} \mathrm{C}$ during transport to the laboratory. The samples were kept at room temperature for $60 \mathrm{~min}$ for liquefaction. Only ejaculates showing normal sperm parameters according to World Health Organization criteria (1999) were used. Depending upon the experiment, ejaculates were used unwashed or were washed twice with PBS (0.05M, pH 7.2) and suspended in PBS.

\subsection{Effect of cell culture and cell free supernatant and washed cells on motility/agglutination of human spermatozoa}

The cervical isolates were grown in brain heart infusion (BHI) broth under shake conditions (150 rpm) at $37^{\circ} \mathrm{C}$ for 24 and $48 \mathrm{~h}$. In each case, $0.2 \mathrm{ml}$ inoculum of overnight culture of the isolate was used to inoculate $20 \mathrm{ml}$ of growth medium (BHI). The flasks were incubated for 24 and $48 \mathrm{~h}$ at $37^{\circ} \mathrm{C}$. The cultures were centrifuged at 10,000 rpm for $20 \mathrm{~min}$ at $4^{\circ} \mathrm{C}$ and clear supernatant was separated. The cells obtained were washed twice 
with PBS ( $\mathrm{pH} 7.2)$ and resuspended in the same buffer.

Human semen ejaculates satisfying the WHO criteria of normal standards were selected and the sperm count adjusted to $40 \times 10^{6} / \mathrm{ml}$ with sterile PBS (50mM, pH 7.2) used as a diluent.

Equal volumes of semen sample $\left(40 \times 10^{6} / \mathrm{ml}\right.$ ) and cell cultures/ cell free supernatant / washed cells $\left(1 \times 10^{7} / \mathrm{ml}\right)$ were mixed and incubated at $37^{\circ} \mathrm{C}$ for $0,1,2$, and $4 \mathrm{~h}$ and the immobilization/agglutination of spermatozoa was observed under light microscope (400X magnification). Experiment was performed in duplicates and the mean values noted. Percent motile sperm were calculated in each case as follows:

$\%$ Motile sperms $=\frac{\text { No. of motile sperms/fie ld }}{\text { No. of total sperms/fie } \mathrm{ld}} \times 100$

\section{Results and Discussions}

Infertility is a subject of world wide interest and importance in both clinical practice and research, affecting both men and women of reproductive age. Infertility could be explained or unexplained (Rowe et al., 2000). In case of explained infertility the reasons are known and the treatment could be possible. Infertility is said to be unexplained in cases where the women is ovulating regularly, has open fallopian tubes with no adhesion or endometriosis and the man has normal sperm production. Intercourse must take place frequently, particularly around the time of ovulation and the couple must have been trying to conceive for at least one or two year (Lunenfeld and Insler, 1993). Unexplained infertility simply means the doctors do not know why the couple is infertile. It is a confession of medical ignorance.

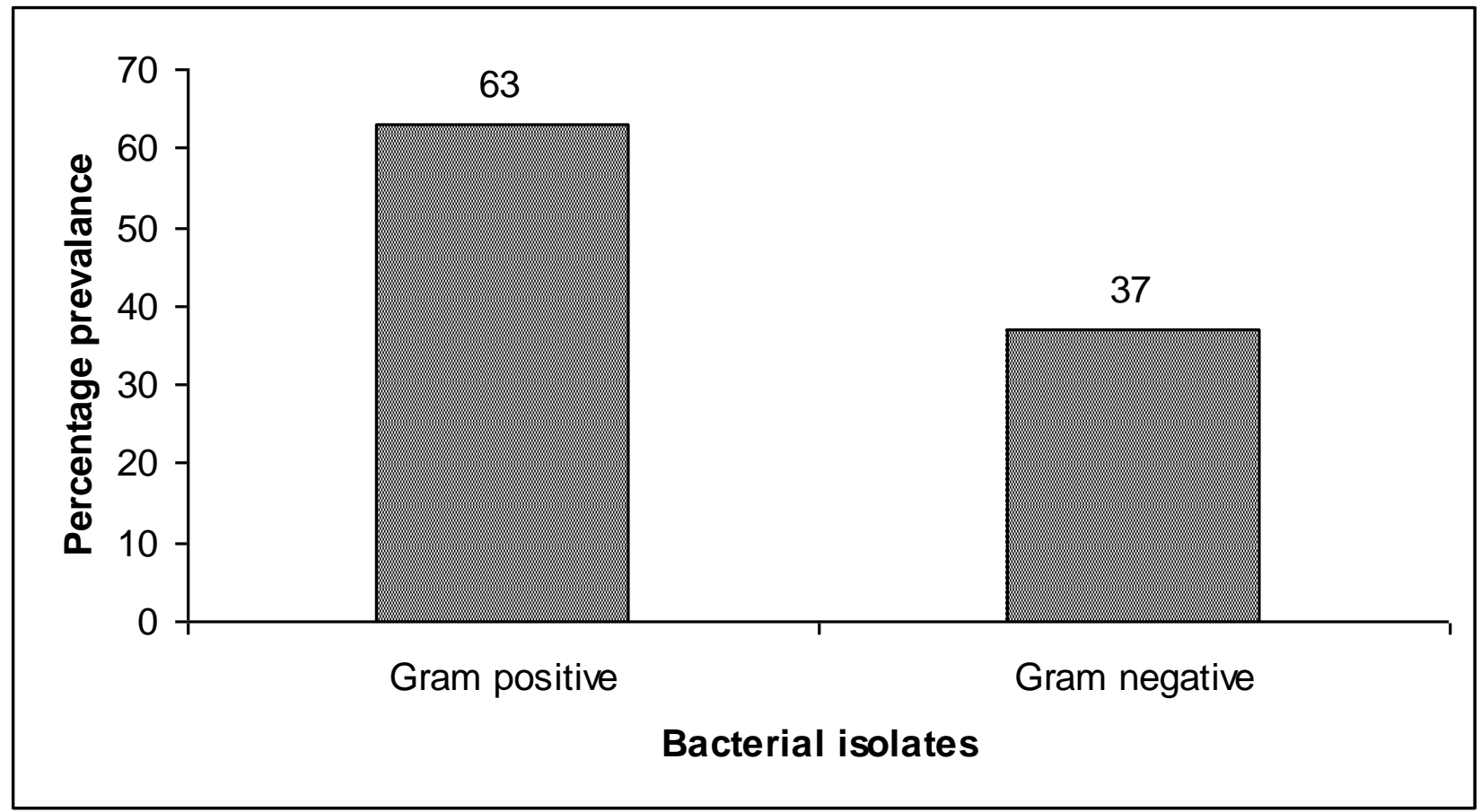

Figure 1: Distribution of Gram positive and Gram negative bacteria in cervices of women with unexplained infertility.

Abnormalities of the cervix and its secretions are reported to be probably responsible for a number of cases of unexplained infertility. Cervical mucus is a complex secretion produced constantly by the secretory cells of the endocervix. If the cervical mucus is friendly to sperm then the sperm should be able to survive in the mucus for Am. J. Biomed. Sci. 2011, 3(2), 84-89; doi: 10.5099/aj110200084 at least 2 days. Normal midcycle mucus acts as a kind of reservoir from which sperms occasionally move to the fallopian tubes where they normally fertilize an egg (Kremer and Jager, 1988). However, it has been observed that spermatozoa do not remain alive in an environment inimicable to sperms because of physical, chemical or (c) 2011 by NWPII. All rights reserved. 
bacteriological reasons. Many workers in the field of infertility have investigated the problems of viscosity, $\mathrm{pH}$, sperm antigens, hyaluronidase and cervical microorganisms (Sparks et al., 1977). But upto now our knowledge in this field is very limited. Very frequently, a broad spectrum of potentially pathogenic microorganism in addition to species of the physiological flora are present in the lower genital tract and may be identified in semen, vaginal fluid and cervical secretions, from normal healthy individuals as well as from subfertile patients (Donders et al., 2000). Many investigators are confronted with difficulties in interpreting the role of physiological bacteria. Therefore, the present study has been undertaken to investigate whether bacteria are able to influence the morphology and low functionality of spermatozoa so that they have a reduced capacity of fertilization leading to infertility.

This study included 16 women on whom routine infertility investigations had been completed. Couples with known causes of infertility were excluded and only those females who were suffering from unexplained infertility were included. Endocervical swab samples taken from cervices were streaked on blood agar plates and the plates were incubated aerobically at $37^{\circ} \mathrm{C}$ for $24-48 \mathrm{~h}$. The isolates were identified according to the Bergey's Manual of Determinative Bacteriology. Most of the microorganisms could be identified upto genus level only. In total 27 isolates were obtained. Gram positive microorganisms were found to be significantly higher in number than the Gram negative organisms (Figure 1). Amongst the various isolates, Staphylococcus $(51.85 \%)$ was the predominant organism present followed by Micrococcus (18.52\%), Streptococcus (11.11\%), E. coli (7.41\%), Bacillus $(7.41 \%)$ and Pseudomonas (3.70\%) (Table 1) These results are in accordance to the earlier studies (Corbishley, 1977) where high prevalence of Staphylococcus $(90 \%)$ in cervical isolates has been reported. When the effect of 24 and $48 \mathrm{~h}$ old culture of cervical isolates on motility of human spermatozoa was studied, it was observed that after $24 \mathrm{~h}, 17$ out of 27 isolates (63\%) significantly decreased the motility of spermatozoa, whereas rest of the isolates failed to do so.
Table 1: Bacteria isolated from cervices of women with unexplained infertility

\begin{tabular}{|l|c|c|}
\hline Type of bacteria & Number & Percentage \\
\hline Staphylococci & 14 & 51.85 \\
\hline Micrococci & 5 & 18.52 \\
\hline Streptococci & 3 & 11.11 \\
\hline Bacillus & 2 & 7.41 \\
\hline Escherichia coli & 2 & 7.41 \\
\hline Pseudomonas & 1 & 3.70 \\
\hline Total & 27 & 100 \\
\hline
\end{tabular}

Immotility of spermatozoa did not increase on incubation of $48 \mathrm{~h}$ old cell culture with semen sample as compared to $24 \mathrm{~h}$ old cell culture. Further, the results on the effect of cell free supernatant from 24 and $48 \mathrm{~h}$ old culture on motility of human spermatozoa showed same number of isolates decreasing the motility of spermatozoa. When, agglutination of human spermatozoa by 24 and $48 \mathrm{~h}$ old cell culture/washed cells/cell free supernatant was studied, the results showed agglutination of human spermatozoa by $18.52 \%$ isolates belonging to Bacillus sp., E. coli, Streptococcus sp., Micrococcus sp. and Staphylococcus sp. Agglutination of human spermatozoa could only be observed with cell culture and washed cells and not with supernatant of any of the isolates (Figure $2 a, b)$.

In conclusion the present results show that genital tract of the women with unexplained infertility have microorganisms in their cervices which either themselves or by producing some extracellular metabolites inhibit sperm motility. In spite of the work that has been done in many countries concerning female genital tract microbiology, it is realized that we are still at the 
beginning in particular, with respect to microorganisms in genital secretions and their clinical significance. This has to be the field of further extensive research.

A

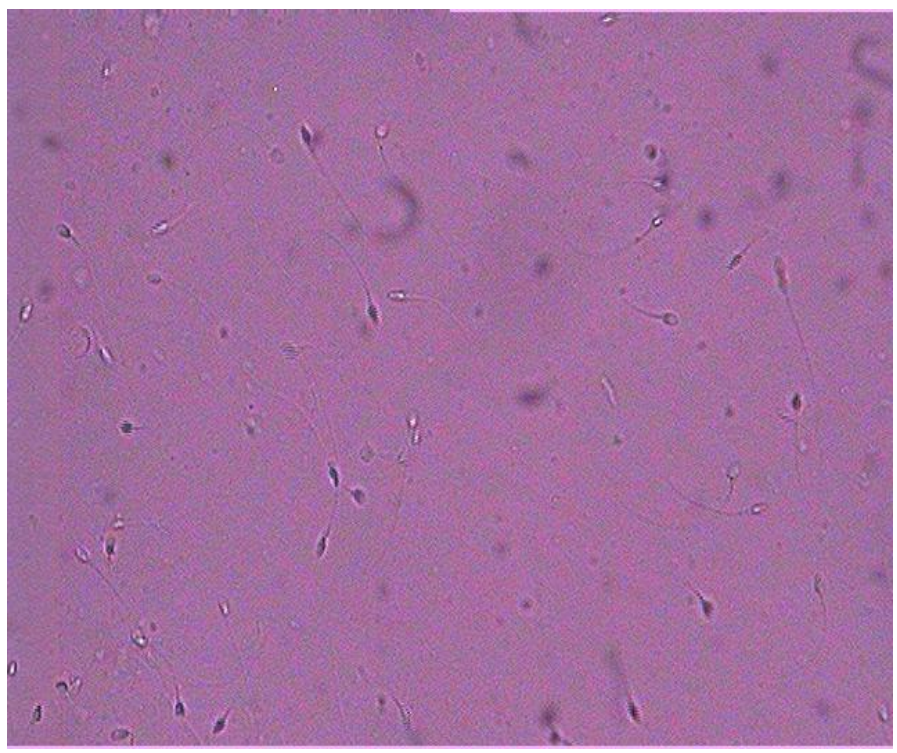

B

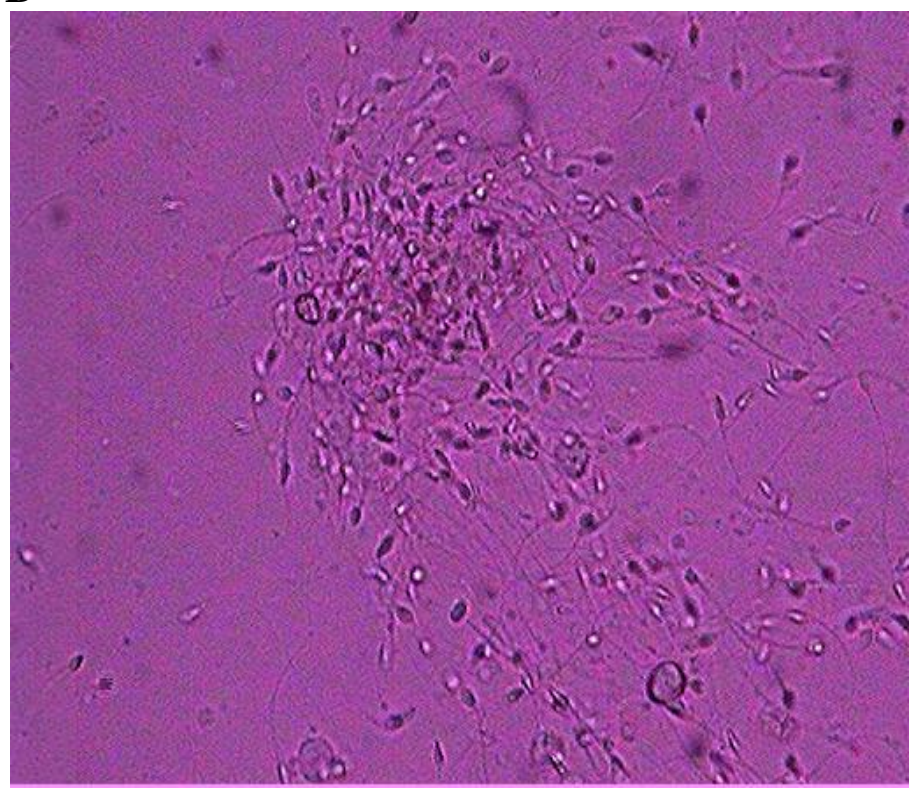

Figure 2: (a) Normal human sperm sample observed at X400 magnification. (b) Agglutination of human spermatozoa after mixing 24 and $48 \mathrm{~h}$ old cell culture/washed cells observed at X400 magnification.

\section{References}

Am. J. Biomed. Sci. 2011, 3(2), 84-89; doi: 10.5099/aj110200084
1. Comhaire FH, Mahmoud AMA, Depuydt CE, Zalata AA \& Christophe AB (1999) Mechanisms and effects of male genital tract infection on sperm quality and fertilizing potential: the andrologist's viewpoint. Human Reproduction Update 5:393-398. DOI: 10.1093/humupd/5.5.393.

2. Khalili MB and Sharifi-Yazdi MK (2001) The effect of bacterial infection on the quality of human's spermatozoa. Ir $J$ Publ Health 30:119-122.

3. Naessons A, Foulon W, Debrucker P, Devroey $\mathrm{P} \&$ Lauwers S (1986) Recovery of microorganisms in semen. Fertil Steril 45: 101105.

4. Golshani M, Taheri S, Eslami G, Suleimani Rahbar AA, Fallah F \& Goudarzi H (2006) Genital tract infection in asymptomatic infertile men and its effect on semen quality. Ir J Publ Health 35:81-84.

5. Fowler JE (1981) Infections of the male reproductive tract and infertility: a selected review. J Androl 2:121-131.

6. Cottell E, Harrison RF, Maccaffery M, Walsh T, Mallen EM \& Barry-Kinsella C (2000) Are seminal fluid microorganisms of significance or merely contaminants? Fertil Steril 74: 465470.

7. Hok TT, Leon LK \& Tijat NT (1967) Comparative bacteriology of endocervical mucus. Am J Obstet Gynecol 98:781-783.

8. Bergey's Manual of Determinative Bacteriology (1994) Bergey DH \& Holt GJ. $9^{\text {th }}$ Ed. Lippincott Williams and Wilkins, Baltimore, Maryland U.S.A.

9. World Health Organisation (1999) WHO laboratory manual for the examination of human semen and semen cervical mucus interaction. Cambridge University Inc, Cambridge, UK. $4^{\text {th }}$ Ed. pp 1-138.

10. Rowe PJ, Comhaire FH, Hargreave TB \& Mahmoud AMA (2000) Clinical investigation of the infertile male. In: WHO Manual for the Standardized Investigation, Diagnosis and Management of the Infertile Male. Cambridge University Press, Cambridge.

11. Lunenfeld B \& Insler V (1993) Infertility: the dimension of the problem. Edinburgh: Churchill Livingstone, $2^{\text {nd }}$ Ed. pp 3-7. 
12. Kremer J \&Jager S (1988) Sperm-cervical mucus interaction, in particular in the presence of antispermatozoal antibodies. Hum Reprod 3:69-73.

13. Sparks RA, Purrier BGA, Watt PJ \& Elstein M (1977) The bacteriology of the cervix and uterus. $\mathrm{Br} J$ Obstet Gynaecol 84:701-704. DOI: $\underline{10.1111 / \mathrm{j} .1471-0528.1977 . t b 12684 . \mathrm{x}}$
14. Donders GG, Bosmans E, Dekeermaecker A, Vereecken A, Van Bulck B \& Spitz B (2000) Pathogenesis of abnormal vaginal bacterial flora. Am J Obstet Gynecol 182:872-878.

15. Corbishley CM (1977) Microbial flora of the vagina and cervix. J Clin Pathol 30:745-748. 